\title{
5: $148186369-148188379$
}

National Cancer Institute

\section{Source}

National Cancer Institute. 5: 148186369-148188379. NCI Thesaurus. Code C41663.

Physical location of ADRB2_Gene 